\title{
Effects of oceanographic retention on decapod and gastropod community diversity on seamounts
}

\author{
P. E. Brewin ${ }^{1,4, *}$, K. I. Stocks ${ }^{2}$, D. B. Haidvogel ${ }^{3}$, C. Condit ${ }^{1}$, A. Gupta ${ }^{2}$ \\ ${ }^{1}$ Center for Research in Biological Systems, and ${ }^{2}$ San Diego Supercomputer Center, University of California San Diego, \\ 9500 Gilman Dr., MC 0505, La Jolla, California 92093-0505, USA \\ ${ }^{3}$ Institute of Marine and Coastal Sciences, Rutgers University, 71 Dudley Rd., New Brunswick, New Jersey 08901-8521, USA \\ ${ }^{4}$ Present address: Flat 1, 3 Grove Park, London, SE5 8LT, UK
}

\begin{abstract}
Using global physical and biological datasets, we tested oceanographic retention (factoring out effects of seamount depth and age) as one possible mechanism structuring seamount benthic decapod and gastropod communities. We first determined the relative oceanographic retentive potential (such as from Taylor caps or columns) for individual seamounts based on steady-state theory. This was then separately compared to decapod and gastropod taxonomic distinctness, our metric for the community's response to oceanographic retention. Taxonomic distinctness is a metric based on phylogenetic relatedness between species. Therefore, between-seamount variability in taxonomic distinctness may reflect the effects of long-term oceanographic retention at the seamount spatial scale. Taxonomic distinctness and retention potential varied between seamounts, but retention did not explain variation in taxonomic distinctness. Among decapod communities, variation in taxonomic distinctness was partly explained by seamount summit depth. With respect to previously suggested causal relationships between seamount retention and biogeographic patterns (divergent seamount communities, high rates of endemism, and inferred speciation at the scale of the seamount), we concluded that seamount-scaled oceanographic retention is weak compared to other ecological drivers of community diversity on seamounts. Alternative processes (such as those related to depth), or alternative spatial scales (within each seamount or between seamount groups and chains) must be considered to explain divergent patterns among seamounts for these taxa.
\end{abstract}

KEY WORDS: Seamount · Taxonomic distinctness · Isolation · Gastropod · Decapod · Taylor cap · Taylor column $\cdot$ Retention $\cdot$ Data integration

\section{INTRODUCTION}

The processes driving marine biogeographic patterns are poorly understood. Contemporary marine biogeographic patterns are thought to be, in part, constrained by physical barriers or processes limiting dispersal, similar to terrestrial systems (e.g. Ricklefs 2004). However, physical barriers and/or dispersal pathways in marine systems are not well perceived (Vermeij 2004) and sometimes defy prediction (e.g. Lessios et al. 1998, Wares et al. 2001). Furthermore, despite recent evidence showing that marine populations are less 'open' than previously thought (Swearer et al. 2002), difficulties in defining processes, and aligning their spatio-temporal scales with biological patterns, still exist (Cowen et al. 2006). Theoretical models such as island biogeography (MacArthur \& Wilson 1967), metacommunity dynamics (Leibold et al. 2004), and neutral theory (Hubbell 2001), supported by empirical evidence, have shown a relationship between community isolation/connectivity and biogeographic patterns, contributing to the improved design of conservation networks and the management of fragmented landscapes.

The role of isolation in structuring seamount communities has been widely debated. Seamounts have been conceptualized as habitat 'islands' in the deep-sea because of their elevated topographies and high biomass and biodiversity compared to surrounding benthic and pelagic habitats (see McClain 2007 for 
review). They have also been proposed as 'steppingstones' (Hamilton 1956) of suitable habitat facilitating the extension of a species range (e.g. Gad \& Schminke 2004 for meiofauna, Rogers et al. 2006 for fish). This concept implies more connectivity between seamounts than the island model assumes.

Findings of high levels of endemism and a high rate of discovery of new species on many seamounts (Parin et al. 1997, Richer de Forges et al. 2000, Stocks \& Hart 2007), explained as local speciation due to isolationrelated processes similar to terrestrial islands (Whittaker 1998), support the isolated, 'island' view of seamounts. Recent studies, however, have questioned the prevalence of endemism on seamounts (McClain 2007). A review by Stocks \& Hart (2007) show that reported levels of endemism on seamounts have a wide range, with low or no endemism found as well as high endemism. Samadi et al. (2006) suggest that genetic exchange between seamounts is more frequent than previously assumed, and may be related to the species' dispersal capabilities. Hall-Spencer et al. (2007) reported that $<3 \%$ of coral groups studied from seamounts in the warm NE Atlantic are endemic. In addition, the generally poor taxonomy and vast undersampling of deep-sea species make for low confidence when estimating the true range and endemic status of most seamount species (Stocks \& Hart 2007).

One process that has been proposed to isolate seamount communities is recirculating retention cells. When generated under steady ambient flow, a retention cell is also known as a Taylor cap, or Taylor column if the water is unstratified. Alternatively, the residual mean currents of tidal flow over the seamount can also generate retention (i.e. tidal rectification), presenting oceanographic characteristics that are outwardly similar to Taylor caps/columns with respect to possible isolation effects.

Oceanographic retention is one appropriately scaled process for potentially isolating seamount communities (i.e. limiting dispersal between seamounts) and, if stable over long timescales, may result in ecological and/or evolutionary community divergence between seamounts. Retention cells have been found on many seamounts (Booth 1988, Freeland 1994, Mullineaux \& Mills 1997, Mohn \& Beckmann 2002, review in White et al. 2007).

Seamount retention is not a binary response; it will vary spatially and temporally according to variability in the local oceanic environment, as well as far-field influences. Therefore, it is likely that the potential for retention will vary between seamounts such that there may be a measurable effect on the seamount community along a gradient of retention.

In support of this idea, Parker \& Tunnicliffe (1994) found a prevalence of species with a short-lived or no free larval stage on Cobb Seamount. They hypothe- sized that the local Taylor cap may serve to retain short-lived larvae over the seamount, allowing them to resettle locally, but that longer-lived larvae would be more likely to be advected off the seamount. Mullineaux \& Mills (1997) found that sampled larval concentrations above and around Fieberling Guyot were consistent with modeled tidally rectified recirculation over the seamount.

Here, we test the role of topographically induced vertical and horizontal closed-circulation retention cells on benthic decapod and gastropod taxonomic distinctness. We chose taxonomic distinctness (sensu Warwick \& Clarke 2001) as our metric for the community's response to long-term, seamount-scaled isolation. Taxonomic distinctness measures the path length separating species pairs along the taxonomic hierarchy of genus, family, order, etc. In other words, it estimates the phylogenetic divergence between species implied from Linnaean taxonomy. The contemporary phylogenetic structure of the community is time-integrated by nature and, as such, carries within it the historical record of ecological processes across local (competition, predation) to regional (dispersal) spatial scales (Webb et al. 2002, Wiens \& Donoghue 2004). Therefore, taxonomic distinctness changes in response to the community's ecological history.

A phylogenetic approach to community ecology has been considered in the past, where 'taxonomic diversity' (sensu Simberloff 1970) has been explored using species-to-genus ratios, particularly on islands (see Webb et al. 2002 for review), the expectation being that due to their isolation, islands will have an overdispersion of species per genus compared to mainland populations, despite lower overall species richness (Simberloff 1970). The species-to-genus ratio has been a fundamental tool of biogeographers (Järvinen 1982); however, it has been considered to be 'a crude tool at best' (Harvey et al. 1983). Taxonomic distinctness (or similar metrics reviewed in Webb et al. 2002) advances our understanding of ecological processes by better quantifying the community's phylogenetic structure and highlighting both the similarities and differences of co-occurring species in the community (Webb et al. 2002). With respect to the present study, analysis of taxonomic distinctness between seamount communities may reveal differences in their ecological histories, including the effects of retention.

Taxonomic distinctness is a relatively new metric and is not well tested in the deep-sea, where many species are considered to be rare (Levin et al. 2001), and small differences in sampling effort as well as method can equate to large differences in diversity. However, a growing number of studies have used it, particularly for examining wide-scale differences in benthic communities on continental shelves, slopes, 
and oceanic ridges (e.g. Somerfield et al. 1997, Rowden et al. 2004), and direct analysis of processes over evolutionary time scales (e.g. Poulin \& Mouillot 2003). Any metric of taxonomic distinctness that is based on Linnaean taxonomy assumes primarily that the hierarchy is a good representation of the true continuous phylogeny where all path-lengths are known. However, because this is not likely to be the case at present, taxonomic distinctness may depend on inconsistent or variable taxonomic hierarchical ranks and path-lengths (Ellingsen et al. 2005) rather than real responses to biotic or abiotic interactions. However, Clarke \& Warwick (1999) show that the taxonomic distinctness metrics used here are insensitive to variations in hierarchical branch lengths; therefore, inconsistencies in hierarchical partitions in the present study may have little influence. Importantly, taxonomic distinctness has the reported advantage of being unbiased to sample size or method (Clark \& Warwick 1998, Magurran 2003) and is well suited for analyzing historical datasets, making this metric particularly useful for examining accumulated seamount species inventories such as those available on SeamountsOnline http://pacific.sdsc.edu/seamounts/.

Two components of taxonomic distinctness are used, average taxonomic distinctness (AvTD) and variation in taxonomic distinctness (VarTD). AvTD is likened to the 'species breadth' of the community, and VarTD measures how those species are distributed among higher taxonomic levels (Warwick \& Clarke 2001).

We tested the hypothesis that isolation via oceanographic retention has a negative effect on AvTD (i.e. reduced species breadth with increased isolation) and a positive effect on VarTD (i.e. clustering of species within higher ranks with increased isolation). In terrestrial systems, isolation (either contemporary or historical) is often manifested in the community as elevated rates of speciation, potentially leading to unique species assemblages within the region and high frequencies of locally endemic species (e.g. Ricklefs 2004). Our approach assumed that (1) the process is primarily constrained to individual seamounts and not seamount chains or groupings, and (2) that this process is stable over time such that a measurable effect in the community is likely.

In the present study, benthic mobile Decapoda and Gastropoda were examined separately. They represent 2 areas of taxonomic strength in our resource for seamount species data, SeamountsOnline (Stocks 2005), and, in addition, may reflect different dispersal capabilities (based on limited larval life history data provided by Grantham et al. 2003). Because the dispersal potential of species within an assemblage varies widely (Grantham et al. 2003), partitioning the assemblage based on dispersal potential is useful to better understand how the effects of retention vary along the continuum of poor to good dispersers.

To quantify retention, we derived a synthetic measure of retention potential of individual seamounts based on steady-state Taylor column/cap theory. Here, retention potential is used in the context of a possible driver of isolation over periods long enough to induce an observable ecological response in the benthic community. If long-term stability in oceanographic retention is needed for community divergence between seamounts to occur, then a steady-state approach is most appropriate for predicting such a pattern. Retention potential is derived from multiple globally accessible sources of seamount topographical and oceanographic data.

We partialled out the role of 2 other potential factors (proxies) structuring seamount communities: age and depth. Because seamounts vary in age, communities may also vary according to the time span over which they have developed. In other marine and terrestrial systems, age of the community has been implicated in explaining much of the contemporary community structure (e.g. Mouquet et al. 2003). We partialled out the effect of seamount summit depth as a proxy for factors that vary throughout the water column. It is widely known that the deep sea is stratified in both physical and biological properties (Levin et al. 2001); factors causing vertical zonation on seamounts may also play a role in determining community taxonomic distinctness.

To conduct our analysis, we used a data integration engine (a mediator) called Cartel (Stocks et al. in press) and a scientific workflow system called Kepler (Ludäscher et al. 2006). Cartel has the ability to create new datasets by combining information from multiple types of data sources (e.g. raster images, relational databases) that can either be local or online. Using the Cartel integration engine, we dynamically collected the data needed for comparative analysis. Kepler, the workflow engine, is a reusable network of data acquisition and computation modules defined within a scientific workflow environment. Kepler interoperates with Cartel to collect the necessary datasets and then uses R (R Development Core Team 2007) to perform statistical analyses - it automates multi-step data extraction, reformatting, and processing tasks. To our knowledge, this is the first study to take advantage of this emergent data integration technology in this domain.

\section{MATERIALS AND METHODS}

Taxonomic distinctness. All seamount species data were collected from SeamountsOnline (Stocks 2005), an online database of species distributions on sea- 
mounts. SeamountsOnline is compiled from the literature and the data holdings of individual researchers and institutions. At present, SeamountsOnline represents the most comprehensive single source of seamount biodiversity data. AvTD and VarTD were calculated based on species presence-absence data.

Selecting seamounts: Seamounts examined in the present study, herein referred to as 'observed seamounts' (Fig. 1), were selected based on quantity (number of species identifications) and quality (definitive species) of available species occurrence data. The Decapoda and Gastropoda met our criteria across 37 and 29 seamounts, respectively, with 16 seamounts in common between the 2 taxonomic groups. Actively venting seamounts were not included. Tasmanian seamounts (data reported by Koslow et al. 2001) were not included in the present study, despite extensive species records from these seamounts, due to high uncertainties in numerous physical attributes needed for retention model development and poor estimates of community age for regression analysis (see below).

Selecting species data: The final species list contained only mobile benthic species (or potentially mobile benthic species based on their family characteristics) as determined from published sources and taxonomic authorities (Brusca \& Brusca 1990, Bauer
2004, B. Marshal pers. comm., J. Martin pers. comm.). Tentative species identifications were used only when no other species in that genus were recorded on a given seamount. This criterion may have led to a somewhat conservative number of species used in the present study. All species names in SeamountsOnline were compared to the Catalog of Life: 2006 Annual Checklist (CoL) (www.catalogueoflife.org) or MarBEF (2004) for correct spelling and detection of synonyms. For the purpose of our study, if the species was not found in either data source, then the name was assumed to be correct. Therefore, some species synonyms may not have been eliminated, possibly overestimating the number of species in the final species list.

Constructing taxonomic hierarchies: Multiple sources of published species taxonomies were used in order to obtain full taxonomic hierarchies for decapods and gastropods: CoL, MarBEF (2004), Systema Naturae 2000 (Brands 2006) and the peer-reviewed literature. Taxonomic levels used for Decapoda were: order, suborder, infraorder, superfamily, family, genus, and species. Levels used for Gastropoda were: class, subclass, order, superfamily, family, genus, and species. Steps between taxonomic levels were equally weighted, and the maximum path length between species was set to 100 .

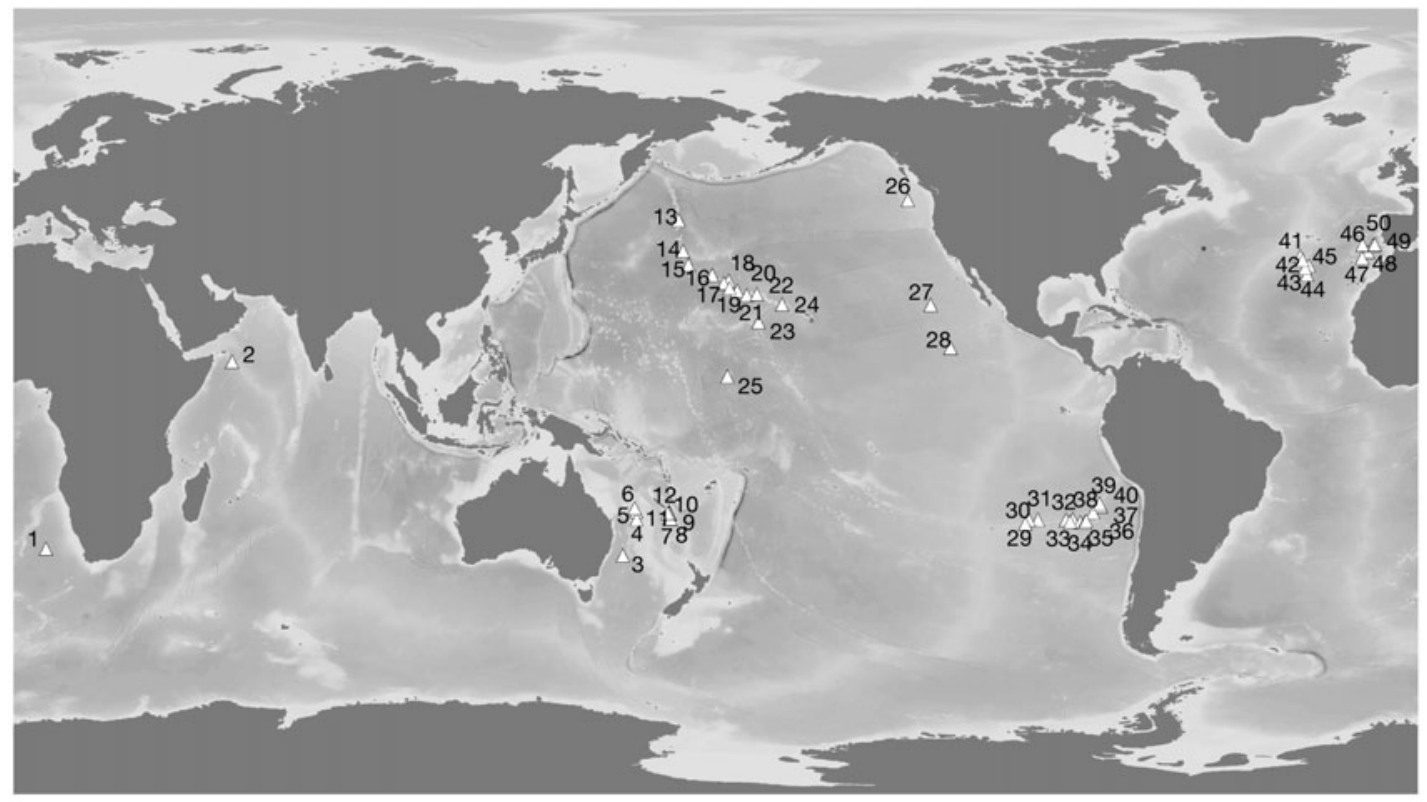

Fig. 1. Map of seamounts examined in the present study. 1: Vema Seamount; 2: Error Seamount; 3: Taupo Seamount; 4: Capel Seamount; 5: Argo Seamount; 6: Nova Bank; 7: Kaimon Maru Seamount; 8: Sponge Seamount; 9: Jumeau E. Seamount; 10: Jumeau W. Seamount; 11: Stylaster Guyot; 12: Antigonia Seamount; 13: Multipeak Seamount; 14: Kimmei and Koko Seamount; 15: Kammu Seamount; 16: Townsend Cromwell Seamount; 17: Nero Seamount; 18: Ladd Seamount; 19: Salmon Bank; 20: Bank 8; 21: Northampton Seamount; 22: Raita Bank; 23: Horizon Tablemount; 24: Twin Banks; 25: Magellan Rise; 26: Cobb Seamount; 27: Seamount 350; 28: Dowd Guyot; 29: Rock Seamount; 30: Ichthyologists Seamount; 31: Cupole Seamount; 32: Mayday Seamount; 33: Pearl Seamount; 34: Amber Seamount; 35: Baral Guyot; 36: Great Bol'shaya Seamount; 37: New (SE Pacific) Seamount; 38: Ichthyandr Seamount; 39: Professor Mesyatzev Seamount; 40: Ecliptic Seamount; 41: Atlantis Seamount; 42: Plato Seamount; 43: Hyeres Seamount; 44: Great Meteor Tablemount; 45: Cruiser Tablemount; 46: Josephine Seamount; 47: Seine Seamount; 48: Ampere Seamount; 49: Gettysburg Seamount; 50: Oromonde Seamount 
Seamount retention model. A diagram summarizing the dimensional parameters used in the present study is shown in Fig. 2. Dimensional and non-dimensional parameters, and their formulae, are listed in Table 1. Seamount topographical data were collected from
Seamount Catalog (www.earthref.org), where multibeam bathymetry data (where the sounding was tracked over the seamount summit) or data from published sources were available. If no published data could be found, we derived seamount heights from the

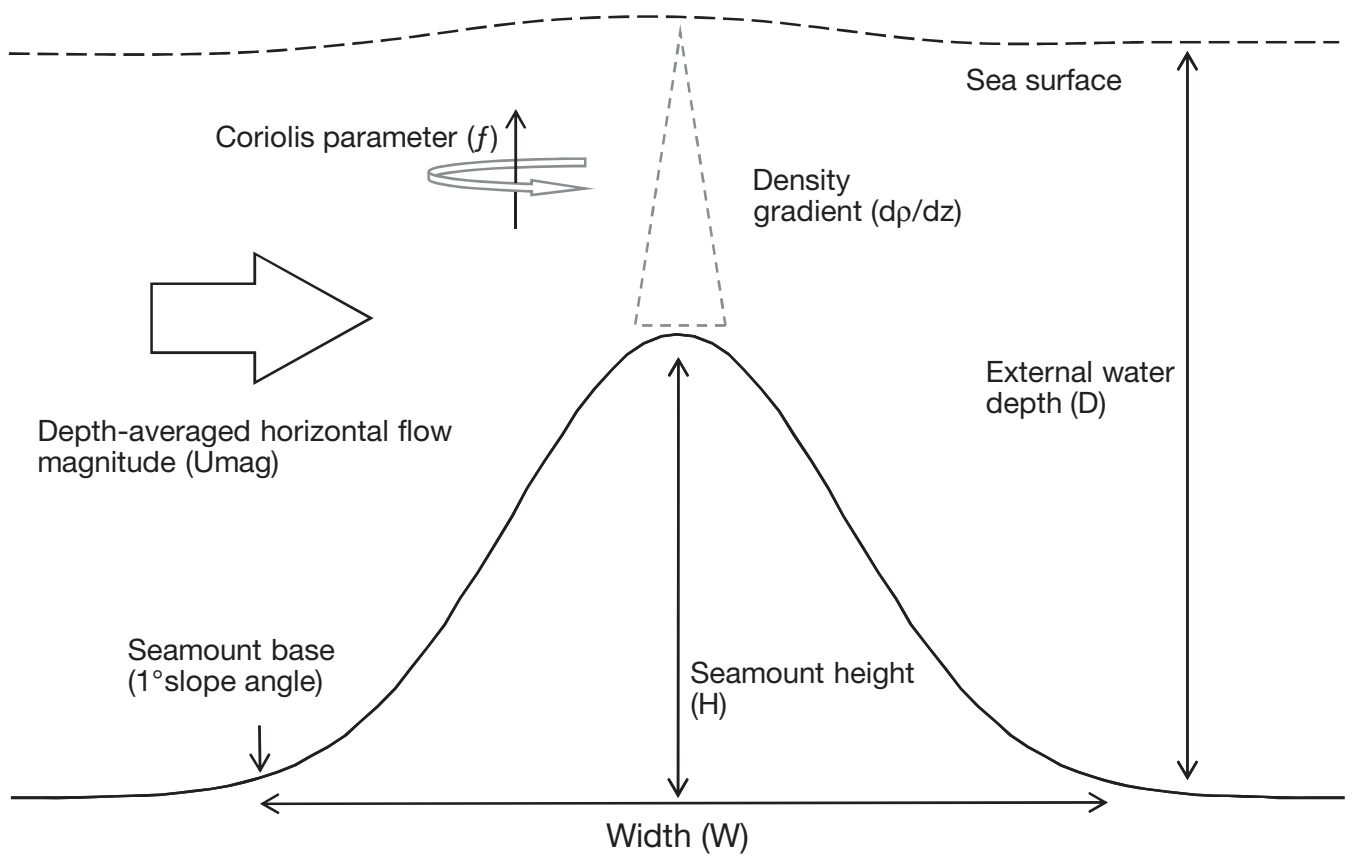

Fig. 2. Diagram of parameterized factors used in deriving retention potential of seamounts

Table 1. Summary of raw dimensional data and derived non-dimensional numbers, and their formulae, used for determining seamount retention potential

\begin{tabular}{|c|c|c|c|}
\hline Variable name & Variable symbol & Units & Formula \\
\hline \multicolumn{4}{|l|}{ Raw dimensional data } \\
\hline Seamount latitude/longitude & Lat / Lon & Dec degrees & \\
\hline External water depth & D & $\mathrm{m}$ & \\
\hline Seamount height & $\mathrm{H}$ & $\mathrm{m}$ & \\
\hline Seamount summit depth & $\mathrm{d}$ & $\mathrm{m}$ & $\mathrm{D}-\mathrm{H}$ \\
\hline Seamount width & W & $\mathrm{m}$ & \\
\hline Surface and summit density & $\rho o, \rho s$ & $\mathrm{~kg} \mathrm{~m}^{-3}$ & UNESCO (1983) \\
\hline Zonal and meridional flow & Uu, Uv & $\mathrm{m} \mathrm{s}^{-1}$ & \\
\hline \multicolumn{4}{|l|}{ Constants } \\
\hline Gravitational acceleration & g & $\mathrm{m} \mathrm{s}^{-2}$ & 9.8 \\
\hline Reference density & $\rho \_0$ & $\mathrm{~kg} \mathrm{~m}^{-3}$ & 1000 \\
\hline Earth's angular velocity & $\Omega$ & rads s ${ }^{-1}$ & $7.27 \times 10^{-5}$ \\
\hline \multicolumn{4}{|l|}{ Derived dimensional data } \\
\hline Density gradient & $\mathrm{d} \rho / \mathrm{dz}$ & $\mathrm{kg} \mathrm{m}^{-4}$ & $(\rho o-\rho s) / d$ \\
\hline Brunt-Väisälä frequency & $\mathrm{N}$ & $\mathrm{s}^{-1}$ & {$\left[-\left(g / \rho \_0\right) \times(d \rho / d z)\right]^{1 / 2}$} \\
\hline Horizontal flow magnitude & Umag & $\mathrm{m} \mathrm{s}^{-1}$ & $\left(U u^{2}+U v^{2}\right)^{1 / 2}$ \\
\hline Coriolis parameter & $f$ & $\mathrm{~s}^{-1}$ & $2 \times \Omega \times \sin ($ Lat $)$ \\
\hline \multicolumn{4}{|c|}{ Derived non-dimensional numbers } \\
\hline Fractional height & ho & & $\mathrm{H} / \mathrm{D}$ \\
\hline Rossby number & Ro & & Umag / $(f \times W)$ \\
\hline Burger number & B & & $(\mathrm{N} \times \mathrm{H}) /(f \times \mathrm{W})$ \\
\hline R-S fractional height & ho $\mathrm{Ro}^{-1}$ & & ho / Ro \\
\hline
\end{tabular}


relationship of seamount height versus radius in the style of Smith (1988). For this analysis, we used published data from Smith (1988) and seamount radii measured from ETOPO-2 v.2 bathymetry (US Department of Commerce 2006) (viewed in ESRI ArcMap v9.1), where seamount radii were measured from the isobath marking a seamount slope angle of $<1^{\circ}$ at the seamount base. This analysis produced the binomial expression $y=-4 \times 10^{-6} x^{2}+0.2607 x-60.152(n=143$, $\mathrm{r}^{2}=0.89$ ), where $y$ represents seamount height and $x$ is the seamount radius, reflecting the truncated shape of many of the larger seamounts (Smith 1988).

Temperature and salinity data at the sea surface and the depth at the seamount summit were collected from the World Ocean Atlas one-quarter degree annual mean dataset (Boyer et al. 2006). The temporal and spatial resolution of these data were thought to be suitable for examining physical and biological processes at the scale of the seamounts chosen. Seawater density was derived from temperature, salinity, and depth using UNESCO (1983) routines. Depth-averaged ( $\mathrm{n}=40$ depths) and time-averaged $(\mathrm{n}=60 \mathrm{mo})$ meridional and zonal flow data were collected from Asia-Pacific Data-Research Center's SODA-POP V1.4.3 model for the one-half degree spatial resolution dataset (Carton et al. 2005). Because the SODA-POP model assimilates available temperature and salinity observations and because we subsequently averaged the SODA-POP data, the net effects of both steady impinging flow (Taylor caps/columns), as well as the circulation due to time-varying flows (e.g. tides, mesoscale eddies, etc.), are potentially combined in these flow estimates. However, it is likely that only the large-scale, low-frequency flow field is resolved at the space/time scales of the World Ocean Atlas.

To visually evaluate the retention potential at individual seamounts, we plotted the non-dimensional Burger number (B) and Rossby-scaled (R-S) fractional height in the style of Huppert (1975). B and R-S represent the competing vertical and horizontal forces, respectively, driving the formation of seamount retention cells. For a Gaussian-shaped structure, Huppert (1975) demonstrates that the critical value of scaled height is $<4$ for weakly stratified flows $(\mathrm{B}<1)$ and decreases exponentially with increasing stratification (B > 1). Initial examination of this plot (Fig. 3) showed that, in general, values for R-S fractional height at observed seamounts were large compared to Huppert's (1975) critical conditions. Therefore, we used R$\mathrm{S}$ fractional height as the predictor variable for which retention potential at observed seamounts can be defined.

To evaluate whether the observed seamounts represent the range of retention potential among seamounts in general, we compiled a set of 'non-observed

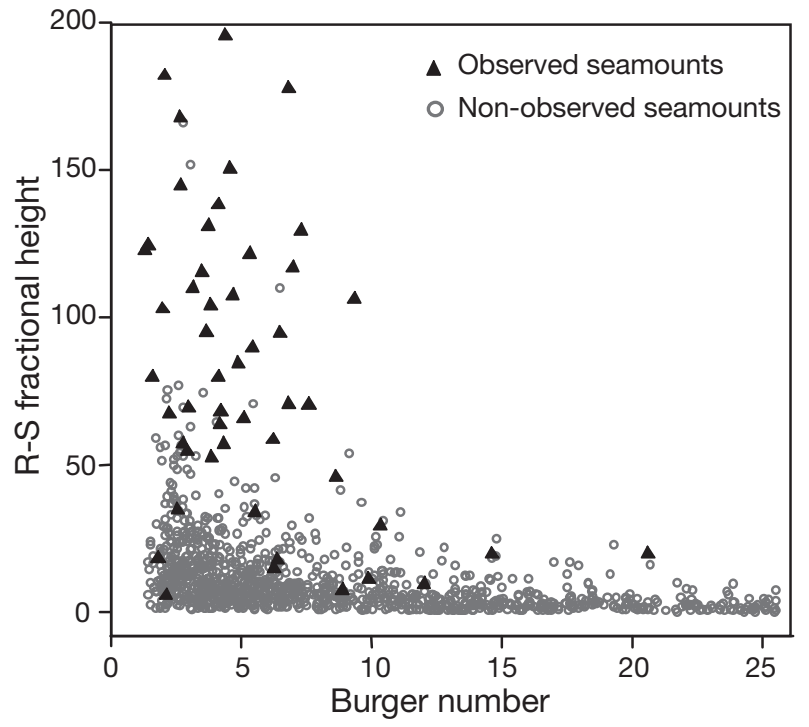

Fig. 3. Plot of observed and non-observed seamounts in retention space. Note that the $x$-axis has been truncated for visual clarity (the maximum Burger number is 117.09)

seamounts' for comparative purposes. We used location and size information for 15000 seamounts from Wessel (2001), but removed seamounts within 2 radii of another seamount (because between-seamount interference is not accounted for in our retention model; $\mathrm{C}$. Mohn pers. comm.), and those within $1^{\circ}$ of the equator, where geostrophic dynamics break down. A total of 1235 seamounts remained after filtering. The majority were deep (mean base depth $=4243 \mathrm{~m}$ ), relatively small (mean height $=1712 \mathrm{~m}$ ), and occupied less than half of the water column (mean fractional height $=$ $0.41)$.

R-S fractional height and Burger numbers were then calculated for non-observed seamounts. Wessel's (2001) predicted radii were ground-truthed against ETOPO-2 V.2 bathymetry (viewed in ESRI ArcMap V9.1). The predicted seamount location and radius proved to be suitably accurate for our purposes, being well aligned with the seamount base seen in ETOPO as defined by a slope of $<1^{\circ}$. However, Wessel's predicted seamount heights varied widely from measured heights (possibly due to the Gaussian assumption of seamount shape in their prediction algorithm; Wessel \& Lyons 1997). Therefore, the relationship for seamount height versus radius derived above was also used for non-observed seamounts.

Seamount age and summit depth. Age estimates for each seamount were collected from published sources. Where published age estimates could not be found for observed seamounts, we estimated the age from available data for surrounding seamounts. In the case of linear hot-spot seamount chains that have been wellstudied (such as the Hawaiian/Emperor Seamount 
Chain), linear regression analysis of distance versus age could be done, and the equation of those relationships was used to estimate missing seamount ages (Wessel 2007). If seamounts were not part of a wellstudied chain, then the age of the underlying plate was used to infer seamount age (A. Koppers \& A. Davis pers. comm.) based on plate ages of Atwater \& Severinghaus (1989). Published seamount summit depths were collected from SeamountsOnline.

Statistical analysis and computational framework. Multiple regression was used to determine the pure effect of seamount retention potential (R-S fractional height) on AvTD and VarTD of each seamount, with seamount age and summit depth as partial factors (Legendre \& Legendre 1998). All data were examined for normality by visual examination of normal probability plots, and statistically by using the ShapiroWilks' goodness-of-fit test. Data that did not meet normality criteria were appropriately transformed prior to multiple regression. Independent variables showed no correlations that would have an appreciable effect on variance inflation.

In order to efficiently collect and integrate biological and physical data from multiple online sources, we employed Cartel, an information integration engine originally developed to integrate relational data sources (Stocks et al. in press), recently extended to handle the integration of spatio-temporal information. Data acquisition and processing were executed in a Kepler V1.0b2 (http://kepler-project.org) workflow environment (Ludäscher et al. 2006). All post-data acquisition statistical analyses (AvTD, VarTD, regression, normality tests, correlation) were programmed in R (R Development Core Team 2007). A schematic diagram of the Kepler workflow is available from the corresponding author.

\section{RESULTS}

\section{Taxonomic distinctness}

AvTD and VarTD of the seamounts for Decapoda and Gastropoda are shown in Fig. 4 and Table 2. Both AvTD and VarTD varied widely between seamounts, having similar means and ranges between the 2 taxonomic groups (Fig. 4). Seamounts having values outside the upper and lower $10 \%$ quantile are labeled according to Fig. 1. A stated property of taxonomic distinctness is that, unlike other estimates of diversity, it is unbiased by varying numbers of species observed (Warwick \& Clarke 2001). This was confirmed here, as AvTD and Var TD were not correlated with the number of species recorded for each seamount (AvTD Pearson's correlation $=0.204, \mathrm{df}=66, \mathrm{p}=0.10$; VarTD
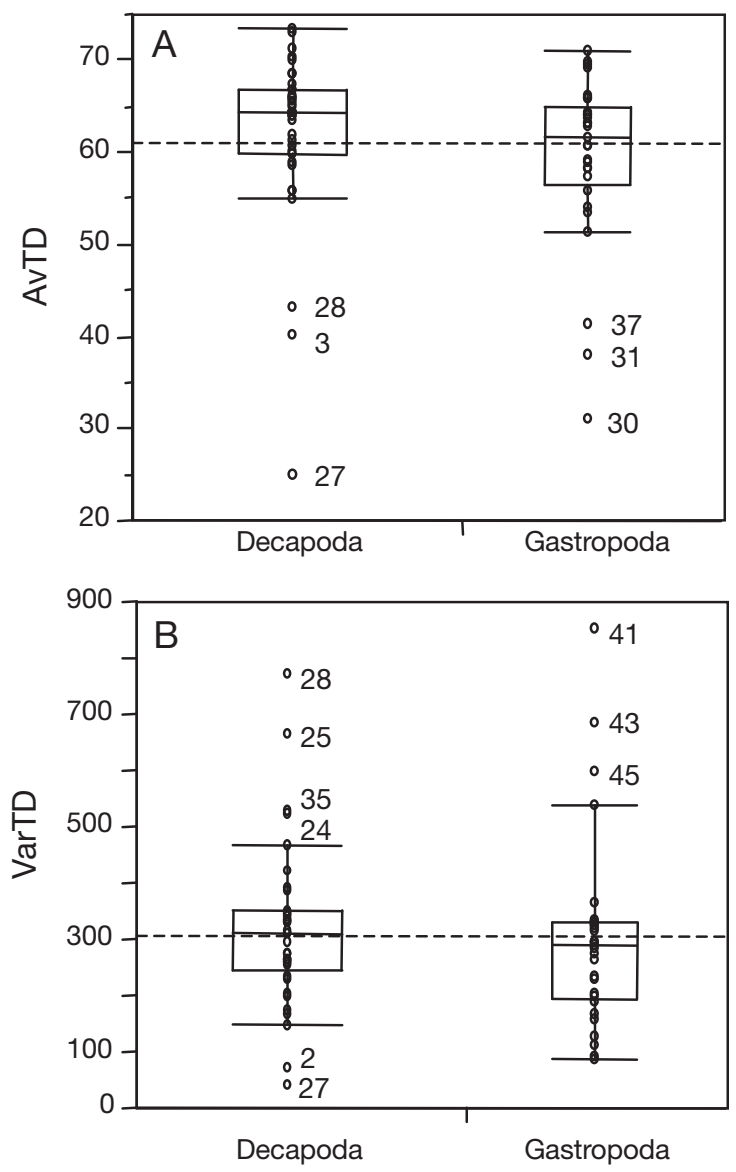

Fig. 4. Box-and-whisker plots of: (A) average taxonomic distinctness (AvTD) and (B) variation in taxonomic distinctness (VarTD) for decapods and gastropods. Boxes: $90 \%$ quantile; lines: $10 \%$ quantile. Overall means are also shown (dashed lines). Seamount outliers are numbered according to Fig. 1

Pearson's correlation $=0.147, \mathrm{df}=66, \mathrm{p}=0.24$ ). It is also important to note that average distance between species pairs (i.e. AvTD) varied independently of the variation in distance between species pairs (i.e. VarTD) (Pearson's correlation $=0.096, \mathrm{df}=66, \mathrm{p}=0.44$ ).

To explore the importance of seamount-scaled processes on decapod and gastropod communities generally, we calculated the correlations for decapod AvTD versus gastropod AvTD and decapod VarTD versus gastropod VarTD for those seamounts where both decapods and gastropods were found ( $\mathrm{n}=16$; Table 2 ). Here, we expected a significant correlation between the 2 groups if there was an overwhelming effect of seamount-scaled processes on the seamount community on the whole. Using transformed data (see Table 4), no correlation was found for decapod versus gastropod AvTD (Pearson's correlation = 0.047, $\mathrm{df}=14$, $\mathrm{p}=0.86$ ) or VarTD (Pearson's correlation $=0.112, \mathrm{df}=$ $14, \mathrm{p}=0.67)$. 
Table 2. Summary of data used in multiple regression analysis for average taxonomic distinctness (AvTD) and variation in taxonomic distinctness (VarTD) in decapods and gastropods. Also shown for each seamount is the number of species used in AvTD and VarTD calculations (S) and the Burger number. Age estimates according to the sources shown. Seamounts are numbered according to Fig. 1. MYA: million years ago

\begin{tabular}{|c|c|c|c|c|c|c|c|c|c|c|c|}
\hline \multirow[b]{2}{*}{$\begin{array}{l}\text { Sea- } \\
\text { mount }\end{array}$} & \multicolumn{3}{|c|}{ Decapoda $\ldots$} & \multirow[b]{2}{*}{$\mathrm{S}$} & \multicolumn{2}{|c|}{ Gastropoda -} & \multirow{2}{*}{$\begin{array}{c}\text { R-S } \\
\text { fractional } \\
\text { height }\end{array}$} & \multirow{2}{*}{$\begin{array}{l}\text { Burger } \\
\text { number }\end{array}$} & \multirow{2}{*}{$\begin{array}{c}\text { Summit } \\
\text { depth (m) }\end{array}$} & \multirow{2}{*}{$\begin{array}{l}\text { Seamount } \\
\text { age (MYA) }\end{array}$} & \multirow[t]{2}{*}{ Source } \\
\hline & $\mathrm{tt}^{\mathrm{S}}$ & AvTD & VarTD & & AvTD & VarTD & & & & & \\
\hline 1 & 17 & 70.17 & 166.48 & 7 & 65.99 & 125.87 & 58.81 & 6.21 & 86 & 72 & Geldmacher et al. (2005) \\
\hline 2 & 10 & 54.92 & 72.16 & & & & 20.03 & 14.59 & 377 & 45 & Rao (1986) \\
\hline 3 & 5 & 40.00 & 195.92 & & & & 57.45 & 2.75 & 796 & 11 & McDougall \& Duncan (1988) \\
\hline 4 & 31 & 64.02 & 261.62 & 24 & 53.31 & 288.49 & 124.74 & 1.41 & 200 & 24 & " \\
\hline 5 & 6 & 70.48 & 230.39 & 5 & 65.71 & 89.80 & 52.85 & 3.85 & 150 & 27 & $"$ \\
\hline 6 & 50 & 63.31 & 322.96 & 29 & 59.25 & 316.24 & 69.71 & 2.96 & 250 & 28 & $"$ \\
\hline 7 & 78 & 64.83 & 332.35 & 59 & 62.99 & 321.05 & 18.23 & 6.37 & 220 & 24 & $"$ \\
\hline 8 & 85 & 64.14 & 331.68 & 39 & 63.79 & 318.48 & 11.66 & 9.88 & 450 & 24 & $"$ \\
\hline 9 & 48 & 61.96 & 338.32 & 14 & 58.87 & 326.69 & 9.95 & 11.98 & 250 & 26 & $"$ \\
\hline 10 & 67 & 64.35 & 341.40 & 59 & 63.95 & 359.35 & 7.77 & 8.87 & 200 & 26 & $"$ \\
\hline 11 & 47 & 65.75 & 307.53 & 24 & 62.89 & 269.42 & 5.99 & 2.09 & 400 & 26 & $"$ \\
\hline 12 & 68 & 65.13 & 250.98 & 57 & 63.19 & 332.17 & 15.14 & 6.23 & 55 & 26 & " \\
\hline 13 & 8 & 58.67 & 325.65 & & & & 123.16 & 1.31 & 1061 & 60 & Clouard \& Bonneville (2005) \\
\hline 14 & 5 & 55.71 & 304.08 & & & & 80.01 & 1.58 & 360 & 40 & " \\
\hline 15 & & & & 14 & 71.11 & 260.05 & 80.23 & 4.11 & 335 & 41 & Duncan \& Clague (1985) \\
\hline 16 & & & & 12 & 69.05 & 232.43 & 95.00 & 6.46 & 607 & 35 & Clouard \& Bonneville (2005) \\
\hline 17 & & & & 7 & 60.54 & 192.51 & 129.61 & 7.28 & 62 & 27 & $"$ \\
\hline 18 & 5 & 58.57 & 385.71 & 11 & 60.52 & 200.10 & 177.98 & 6.79 & 75 & 27 & $"$ \\
\hline 19 & 8 & 64.29 & 255.10 & & & & 106.62 & 9.34 & 99 & 25 & $"$ \\
\hline 20 & & & & 7 & 63.95 & 109.21 & 117.16 & 6.96 & 64 & 22 & $"$ \\
\hline 21 & 8 & 66.84 & 146.55 & & & & 65.94 & 5.09 & 31 & 27 & $"$ \\
\hline 22 & 8 & 64.29 & 255.10 & & & & 131.36 & 3.74 & 31 & 17 & $"$ \\
\hline 23 & 5 & 64.29 & 459.18 & & & & 34.97 & 2.55 & 1500 & 83 & $"$ \\
\hline 24 & 5 & 60.00 & 522.45 & & & & 70.62 & 7.57 & 99 & 10 & $"$ \\
\hline 25 & 10 & 59.68 & 655.68 & & & & 18.48 & 1.79 & 3150 & 49 & Clouard \& Bonneville (2001) \\
\hline 26 & & & & 16 & 69.52 & 282.09 & 84.67 & 4.89 & 200 & 3 & Clouard \& Bonneville (2005) \\
\hline 27 & 13 & 24.73 & 40.15 & & & & 29.80 & 10.31 & 881 & 20 & Atwater \& Severinghaus (1989) \\
\hline 28 & 7 & 42.86 & 758.02 & & & & 20.23 & 20.56 & 478 & 25 & " \\
\hline 29 & 9 & 68.65 & 258.72 & & & & 57.51 & 4.31 & 330 & 8 & Clouard \& Bonneville (2005) \\
\hline 30 & 23 & 65.44 & 333.62 & 7 & 30.61 & 83.30 & 64.09 & 4.18 & 330 & 9 & " \\
\hline 31 & 32 & 66.68 & 292.18 & 11 & 37.66 & 165.96 & 104.46 & 3.80 & 218 & 11 & $"$ \\
\hline 32 & 7 & 68.71 & 381.32 & & & & 68.53 & 4.21 & 545 & 17 & $"$ \\
\hline 33 & 13 & 63.92 & 307.30 & & & & 95.31 & 3.65 & 530 & 18 & $"$ \\
\hline 34 & 17 & 60.71 & 413.42 & & & & 138.44 & 4.11 & 510 & 15 & $"$ \\
\hline 35 & 9 & 67.46 & 517.13 & & & & 71.14 & 6.79 & 370 & 20 & $"$ \\
\hline 36 & 19 & 66.00 & 270.07 & & & & 115.43 & 3.47 & 160 & 21 & $"$ \\
\hline 37 & 9 & 71.43 & 272.11 & 6 & 40.95 & 186.85 & 46.28 & 8.61 & 270 & 21 & $"$ \\
\hline 38 & 5 & 55.71 & 344.90 & & & & 89.90 & 5.40 & 505 & 23 & $"$ \\
\hline 39 & 5 & 65.71 & 171.43 & & & & 34.32 & 5.49 & 320 & 24 & $"$ \\
\hline 40 & 8 & 61.22 & 260.31 & & & & 150.66 & 4.55 & 230 & 25 & " \\
\hline 41 & & & & 25 & 58.10 & 841.27 & 67.74 & 2.22 & 275 & 61 & Tucholke \& Smoot (1990) \\
\hline 42 & & & & 10 & 53.97 & 225.75 & 55.05 & 2.92 & 500 & 20 & " \\
\hline 43 & & & & 32 & 64.20 & 674.78 & 110.13 & 3.12 & 380 & 19 & $"$ \\
\hline 44 & 13 & 73.08 & 224.91 & 20 & 61.65 & 531.74 & 168.11 & 2.64 & 300 & 33 & $"$ \\
\hline 45 & & & & 30 & 65.91 & 587.90 & 102.94 & 1.99 & 210 & 37 & " \\
\hline 46 & 8 & 73.47 & 199.92 & 7 & 55.78 & 289.69 & 144.92 & 2.66 & 148 & 60 & Geldmacher et al. (2005) \\
\hline 47 & & & & 10 & 51.11 & 285.61 & 107.54 & 4.67 & 165 & 22 & " \\
\hline 48 & & & & 6 & 57.14 & 326.53 & 182.21 & 2.05 & 400 & 31 & $"$ \\
\hline 49 & & & & 6 & 58.10 & 312.02 & 195.75 & 4.37 & 100 & 66 & $"$ \\
\hline 50 & & & & 25 & 69.95 & 156.32 & 121.72 & 5.32 & 100 & 66 & $"$ \\
\hline
\end{tabular}

\section{Seamount retention model}

Burger numbers versus R-S fractional height values of observed seamounts (i.e. those seamounts with species observations examined here) are plotted in Fig. 3.
Overlaid is the distribution of Burger number versus R-S fractional height for non-observed seamounts (i.e. those seamounts from Wessel 2001). The Burger number ranged from 1.47 to 117.09 (truncated in Fig. 3 for clarity of display). Most of the observed seamounts had 
larger R-S fractional heights than the background population of non-observed seamounts. However, the ranges in both R-S fractional height and Burger numbers were similar, indicating that the observed seamounts are reasonably representative of seamounts in general. Note that all observed seamounts exceeded the minimum conditions of R-S fractional height (ho $\mathrm{Ro}^{-1}$ ) $\sim 4$ (Table 2) for retention cell formation defined by Huppert (1975).

A first-order examination of the factors contributing to the variation among observed seamounts (Table 3) shows that high Burger numbers are related primarily to high buoyancy (Brunt-Väisälä frequency) and, to lesser extents, inversely related to seamount width and position on the Earth (Coriolis parameter). R-S fractional height is driven almost equally by actual fractional height of the seamount, Coriolis parameter, and horizontal flow (inversely). Seamount width also contributes to a lesser extent.

\section{Multiple regression}

Model results are shown in Table 4. For decapods, neither variation of AvTD nor of VarTD was explained by seamount retention potential, after removing the effects of summit depth and age. There was a significant $(\mathrm{p}=0.039)$ and negative (estimate $=-0.976$, $t$-value $=-2.16$ ) pure effect of summit depth on AvTD, indicating that the species breadth of decapod communities decreases with increasing seamount depth. The factor summit depth is therefore the main factor in explaining $20 \%$ (multiple $\mathrm{R}^{2}, \mathrm{p}=0.075$, not significant) of variation in AvTD in the full model. Variation in taxonomic distinctness among gastropod communities was not well explained by seamount retention potential either (Table 4). Partial factors of summit depth and age showed no significant explanatory power for AvTD or VarTD.

\section{DISCUSSION}

We examined the contribution of oceanographic retention (e.g. Taylor cones) in driving one aspect of diversity, taxonomic distinctness, in seamount decapod and gastropod assemblages. We hypothesized that higher retention would act to isolate each assemblage and, as hypothesized for islands (Whittaker 1998), lead to reduced species breadth (AvTD) and increased clustering of species within higher ranks (VarTD).

Examination of the AvTD and VarTD for gastropods and decapods showed substantial variation among seamounts (Fig. 4). Because taxonomic distinctness is a phylogenetic-based metric embodying ecological histories, these results suggest that seamount communities are likely to vary in their ecological histories, creating divergence in communities both in terms of species breadth (i.e. width of the taxonomic tree), and dispersion of species within higher taxonomic levels (e.g. number of species per genus, genera per family, etc.). It is not feasible to compare these taxonomic distinctness values to other published studies, because they are sensitive to which and how many taxonomic levels are considered, how large the taxonomic group is that is being considered (e.g. a single order vs. the whole animal community), and the nature and scale of the sampling methods.

Table 3. Pearson's correlation coefficients (below diagonals) and significance (above diagonals, in italics) of component factors $(\mathrm{n}=50)$ for calculating seamount Burger number and R-S fractional height. Probabilities in bold are significant

\begin{tabular}{|c|c|c|c|c|c|}
\hline \multicolumn{6}{|c|}{ Burger number vs. component factors } \\
\hline Burger number & 1 & $<0.0001$ & 0.0012 & 0.2823 & 0.0056 \\
\hline Brunt-Väisälä & 0.6815 & 1 & 0.0835 & 0.8059 & 0.0112 \\
\hline Coriolis parameter & -0.4441 & -0.2472 & 1 & 0.1491 & 0.1053 \\
\hline Seamount height & 0.155 & 0.0356 & 0.207 & 1 & 0.1022 \\
\hline Seamount base width & -0.3863 & -0.3557 & -0.2318 & 0.2338 & 1 \\
\hline \multicolumn{6}{|c|}{ R-S fractional height vs. component factors } \\
\hline & $\begin{array}{c}\text { R-S fractional } \\
\text { height }\end{array}$ & $\begin{array}{l}\text { Fractional } \\
\text { height }\end{array}$ & Coriolis parameter & Horizontal flow & Seamount base width \\
\hline R-S fractional height & 1 & 0.0003 & 0.0001 & $<0.0001$ & 0.1582 \\
\hline Fractional height & 0.4938 & 1 & 0.0062 & 0.0127 & 0.0513 \\
\hline Coriolis parameter & 0.5138 & 0.3818 & 1 & 0.069 & 0.1053 \\
\hline Horizontal flow & -0.5743 & -0.35 & -0.2593 & 1 & 0.0023 \\
\hline Seamount base width & 0.2026 & -0.2772 & -0.2318 & 0.4221 & 1 \\
\hline
\end{tabular}


Table 4. Full model summary and ANOVA table (factors) of multiple regression of average taxonomic distinctness (AvTD) and variation in taxonomic distinctness (VarTD) vs retention potential (R-S fractional height) with Summit, Depth and Age as partial factors. ${ }^{*} \mathrm{p}<0.05$

\begin{tabular}{|c|c|c|c|c|c|c|c|}
\hline & \multicolumn{2}{|c|}{ Full model summary } & Factor & df & SS & $F$ & $\mathrm{p}$ \\
\hline \multicolumn{8}{|c|}{ Decapods } \\
\hline \multirow[t]{4}{*}{$\operatorname{AvTD}^{a}$} & Residual SE & 1.109 & R-S fractional height ${ }^{b}$ & 1 & 0.983 & 0.799 & 0.378 \\
\hline & Multiple $\mathrm{R}^{2}$ & 0.186 & Summit $^{\mathrm{C}}$ & 1 & 5.715 & 4.645 & $0.039^{*}$ \\
\hline & $F_{3,33}$ & 2.513 & $\operatorname{Age}^{c}$ & 1 & 1.923 & 1.535 & 0.224 \\
\hline & $\mathrm{p}$ & 0.075 & Residuals & 33 & 49.886 & & \\
\hline \multirow[t]{4}{*}{$\operatorname{VarTD}^{\mathrm{b}}$} & Residual SE & 4.021 & R-S fractional height ${ }^{b}$ & 1 & 0.019 & 0.001 & 0.972 \\
\hline & Multiple $\mathrm{R}^{2}$ & 0.083 & Summit $^{\mathrm{C}}$ & 1 & 43.904 & 2.716 & 0.109 \\
\hline & $F_{3,33}$ & 0.999 & $\operatorname{Age}^{\mathrm{C}}$ & 1 & 5.758 & 0.356 & 0.555 \\
\hline & $\mathrm{p}$ & 0.405 & Residuals & 33 & 581.949 & & \\
\hline \multicolumn{8}{|c|}{ Gastropods } \\
\hline \multirow[t]{4}{*}{$\operatorname{AvTD}^{\mathrm{a}}$} & Residual SE & 1.239 & R-S fractional height & 1 & 0.779 & 0.507 & 0.483 \\
\hline & Multiple $\mathrm{R}^{2}$ & 0.118 & Summit & 1 & 0.038 & 0.025 & 0.876 \\
\hline & $F_{3,25}$ & 1.114 & $\operatorname{Age}^{b}$ & 1 & 4.957 & 3.225 & 0.085 \\
\hline & $\mathrm{p}$ & 0.362 & Residuals & 25 & 43.566 & & \\
\hline \multirow[t]{4}{*}{$\operatorname{VarTD}^{\mathrm{b}}$} & Residual SE & 4.589 & R-S fractional height & 1 & 1.320 & 0.063 & 0.804 \\
\hline & Multiple $\mathrm{R}^{2}$ & 0.109 & Summit & 1 & 45.151 & 2.144 & 0.156 \\
\hline & $F_{3,25}$ & 1.020 & $\operatorname{Age}^{b}$ & 1 & 28.360 & 1.346 & 0.257 \\
\hline & $\mathrm{p}$ & 0.401 & Residuals & 25 & & & \\
\hline
\end{tabular}

Our hypothesis was not supported-multiple regression analysis found no relationship between predicted oceanographic retention at a seamount and AvTD or VarTD for either decapods or gastropods (Table 4). If our model approach was robust, this suggests that the process of seamount retention is weak compared to other processes in structuring seamount decapod and gastropod taxonomic distinctness. These results do not support previously suggested relationships between seamount retention cells and observed biogeographic patterns (Mullineaux \& Mills 1997, Parker \& Tunnicliffe 1994), and do not support the concept that seamount communities are highly isolated by retention.

Our results are consistent with recent evidence from New Caledonian seamounts, where little genetic structure of 2 species of Eumunida spp. (family Chirostylidae) was found between neighboring seamounts (Samadi et al. 2006). Although our seamount retention model predicts some retention potential for the New Caledonian seamounts (Kaimon Maru, Sponge, Jumeau East and West, Stylaster, Antigonia) (Table 2), their retention potential is the lowest of all observed seamounts, suggesting retention is not sufficient to constrain dispersal of the 2 Eumunida species.

Results in the present study are similar between groups with differing dispersal capabilities (decapods compared to gastropods) - neither showed a relationship to retention. Conversely, Samadi et al. (2006) found that Nassaria problematica, a gastropod with limited dispersal capabilities, shows some genetic divergence between seamounts, as might be expected if there was a significant effect of isolation. However, in the Samadi system and in general, alternative isolation mechanisms besides retention may be operating. High levels of endemism found on seamounts have been interpreted to indicate local speciation resulting from isolation (Wilson \& Kauffmann 1987, Parin et al. 1997, Richer de Forges et al. 2000), though how ubiquitous this endemism is has recently been questioned (McClain 2007, Stocks \& Hart 2007). Indeed, it may be that other oceanographic or behavioral mechanisms have a stronger influence on driving the self-recruitment of seamount populations, as has been suggested for other marine systems (e.g. Wares et al. 2001, Swearer et al. 2002); however, this has not yet been shown for seamount systems.

Further, it is possible that retention affects these communities, but that our model is not appropriate. Ground-truthing our retention model is difficult. Factors in the retention model can be measured or expressed in different ways, such as fractional height being calculated with respect to the local thermocline (e.g. White \& Mohn 2004), the position of local upwelling (e.g. Genin \& Boehlert 1985), or the seamount base (present study), which, in turn, significantly affect Rossby numbers and R-S fractional height estimates (Table 3). This makes comparing R-S frac- 
tional heights and Burger numbers across studies problematic. Furthermore, retention is not a binary condition; if we use Huppert's (1975) criteria as a guide for setting minimum limits on critical conditions, then at least some retention is predicted in all observed and non-observed seamounts by our model. Published field observations that have identified Taylor cones over certain seamounts help validate our model; however, their persistence and frequency are unknown.

If our model is appropriate for estimating long-term average retention, the question remains as to what is contributing to the variation in AvTD and VarTD of seamount communities measured here. The lack of correlation between decapod and gastropod AvTD and decapod and gastropod VarTD suggests that the drivers of decapod and gastropod assemblages differ widely, such that seamount-scaled processes of any kind are likely to play a small part in driving community patterns. This implies that alternative spatial and temporal scales need to be considered. Our retention model is based on time- and space-integrated mean values and is therefore suitably matched to describe species patterns driven by long temporal processes (Ricklefs 1987). However, Gaines \& Denny (1993) suggest that 'extreme values' in processes may be the drivers of marine population dynamics. In this sense, retention may play a short-term role in constraining dispersal, but the periodic shedding of eddies formed over seamounts may be the mechanism by which seamount communities maintain connectivity throughout the region, as has been suggested for Feiberling Seamount (Mullineaux \& Mills 1997). The lack of explanatory power of retention on taxonomic distinctness suggests that low retention or infrequent retention may be enough to homogenize seamount communities throughout a wider region. Richardson (1980) reports bottom trapping of topographically induced eddies above the collective Corner Rise Seamounts. Along seamount chains, flow-topography interactions can be highly complex (Roden 1987). These spatially and temporally complex processes could be better examined with a model that partitions the relative effects of steady-state and time-varying (both periodic and episodic) events (e.g. Goldner \& Chapman 1997).

At within-seamount spatial scales, non-retentionrelated oceanographic processes certainly play a role in structuring seamount communities. We found a significant negative effect of seamount depth on AvTD in decapods, suggesting a depth-related process driving divergent community diversity. Vertical stratification of seamount communities has been reported in terms of community composition (Rogers et al. 2007) and genetic differentiation (e.g. France \& Kocher 1996, Creasey \& Rogers 1999), concurrent with our findings. In the deep-sea, the bathymetric structuring of species diversity and biomass has been related to complex trophic, dispersal, and evolutionary dynamics throughout the entire water column (e.g. Rex et al. 2005). Rex et al. (2006) suggest that decreasing body size with increasing depth may be related to vertical gradients in food sources. In our study, vertical gradients of productivity may be manifest as changes in phylogenetic structure of the community if food becomes a limiting resource at some point along the gradient, leading to competitive exclusion (Huston 1996) or differing predator-prey interactions (e.g. Grant 2000 for deepsea soft sediment communities). If intra-genus competition is high, an under-dispersion of species per genus in the community may result, reflecting divergent biotic interactions at different depths. Similarly, many seamounts are tall enough to cross multiple mid-water density and oxygen clines. Such structuring may be maintained across the region by way of multiple, midocean water masses, giving rise to different rates of connectivity among depth strata. Here, taxonomic distinctness measures were calculated per seamount; the data were not dense enough to examine withinseamount variability with depth. Future examination of seamount community diversity would benefit from a within-seamount stratified approach.

We have shown that seamount oceanographic retention may be weak compared to other processes structuring seamount communities, and that alternative spatial scales need to be considered when delineating 'local' seamount community patterns and processes. In addition, we demonstrated the effective integration of online biological and physical datasets, facilitated by emergent data integration, which is creating new possibilities for exploration and analysis of such data in marine and other ecosystems. In the future, integrated approaches to seamount community dynamics should focus on improving the geographic extent of sampled seamounts using a targeted approach to sampling seamounts with a wide variety of physical characteristics, identification of spatial subdivision of seamount communities across regional scales, and aligning these to small-scale and mesoscale processes within the metacommunity. Such an approach would lead to better identification of conservation and management areas for seamounts and implementation of such policies.

Acknowledgements. We thank X. Qian, L. Situ (University of California San Diego) and J. Evans (Rutgers University) for programming assistance. Thanks also go to B. Marshal (Te Papa: the Museum of New Zealand) and J. Martin (Natural History Museum Los Angeles) for taxonomic advice, to A. Koppers (Scripps Institute of Oceanography) and A. Davis (Monterey Bay Aquarium Research Institute) for advice on geological ages of seamounts, and C. Mohn (National University of Ireland) for helpful discussions on seamount oceanography. A. Berg (Mathworks, University of California San 
Diego) generously provided statistical advice. Thanks to P. Miller and K. Tran for useful assistance in preparing data. Early versions of this manuscript benefited from the comments of L. Levin (Scripps Institute of Oceanography), T. Schlacher (University of the Sunshine Coast) and anonymous reviewers. Parts of this study are based upon work supported by the National Science Foundation under Grant No. 0340839 (K.I.S.). This work was also generously supported by the Gordon and Betty Moore Foundation (Grant Number 050844-002).

\section{LITERATURE CITED}

Atwater T, Severinghaus J (1989) Tectonic maps of the northeast Pacific In: Winterer EL, Hussong DM, Decker RW (eds) The eastern Pacific Ocean and Hawaii. The Geological Society of America, Boulder, CO, p 15-20

Bauer RT (2004) Remarkable shrimps: adaptations and natural history of the carideans. University of Oklahoma Press, Norman

Booth DA (1988) Eddies in the Rockall Trough. Oceanol Acta 11:213-219

Boyer TP, Antonov JI, Garcia HE, Johnson DR and others (2006) World ocean database 2005. In: Levitus S (ed) NOAA atlas NESDIS 60. U.S. Government Printing Office, Washington, DC, DVDs

Brands SJ (comp.) (2006) Systema Naturae 2000. Available at: http://sn2000.taxonomy.nl/

Brusca RC, Brusca GJ (1990) Invertebrates. Sinauer Associates Inc, Sunderland, MA

Carton JA, Giese BS, Grodsky SA (2005) Sea level rise and the warming of the oceans in the SODA ocean reanalysis. J Geophys Res 110:C09006, doi:10.1029/2004JC002817

Clarke KR, Warwick RM (1998) The taxonomic distinctness measure of biodiversity and its statistical properties. J Appl Ecol 35:523-531

Clarke KR, Warwick RM (1999) The taxonomic distinctness measure of biodiversity: weighting of step lengths between hierarchical levels. Mar Ecol Prog Ser 184:21-29

Clouard V, Bonneville A (2001) How many Pacific hotspots are fed by deep-mantle plumes? Geology 29:695-698

Clouard V, Bonneville A (2005) Ages of seamounts, islands and plateaus on the Pacific Plate. In: Foulger GR, Natland JH, Presnall D, Anderson DL (eds) Plates, plumes and paradigms. Geological Society of America Special Paper 388: 71-90

Cowen RK, Paris CB, Srinivasan A (2006) Scaling connectivity in marine populations. Science 311:522-527

Creasey SS, Rogers AD (1999) Population genetics of bathyal and abyssal organisms. Adv Mar Biol 35:1-151

Duncan RA, Clague DA (1985) Pacific plate motion recorded by linear volcanic chains. In: Nairn AEM, Stehli EG, Uyeda S (eds) The ocean basins and margins, Vol 7A. The Pacific Ocean. Plenum, New York, p 89-121

Ellingsen KE, Clarke KR, Somerfield PJ, Warwick RM (2005) Taxonomic distinctness as a measure of diversity applied over a large scale: the benthos of the Norwegian continental shelf. J Anim Ecol 74:1069-1079

France SC, Kocher TD (1996) Geographic and bathymetric patterns of mitochondrial 16S rRNA sequence divergence among deep-sea amphipods, Eurythenes gryllus. Mar Biol 126:633-643

Freeland H (1994) Ocean circulation at and near Cobb Seamount. Deep-Sea Res I 41: 1715-1735

Gad G, Schminke HK (2004) How important are seamounts for the dispersal of interstitial meiofauna? Arch Fish Mar Res 51:43-54
Gaines SD, Denny MW (1993) The largest, smallest, highest, lowest, longest, and shortest: extremes in ecology. Ecology 74:1677-1692

Geldmacher J, Hoernle K, Bogaard PVD, Duggen S, Werner R (2005) New Ar-40/Ar-39 age and geochemical data from seamounts in the Canary and Madeira volcanic provinces: support for the mantle plume hypothesis. Earth Planet Sci Lett 237:85-101

Genin A, Boehlert GW (1985) Dynamics of temperature and chlorophyll structures above a seamount: an oceanic experiment. J Mar Res 43:907-924

Goldner DR, Chapman DC (1997) Flow and particle motion induced above a tall seamount by steady and tidal background currents. Deep-Sea Res 44:719-744

Grant A (2000) Deep-sea diversity: overlooked messages from shallo-water sediments. PSNZ Mar Ecol 21:97-112

Grantham BA, Eckert GL, Shanks AL (2003) Dispersal potential of marine invertebrates in diverse habitats. Ecol Appl 13:108-116

Hall-Spencer J, Rogers AD, Davies J, Foggo A (2007) Deepsea coral distribution on seamounts, oceanic islands and continental slopes in the NE Atlantic. Bull Mar Sci 81(Suppl 1):135-146

Hamilton EL (1956) Sunken islands of the mid-Pacific mountains. Geological Society of America Memoirs 64, Geological Society of America, New York

> Harvey PH, Colwell RK, Silvertown JW, May RM (1983) Null models in ecology. Annu Rev Ecol Syst 14:189-211

Hubbell SP (2001) The unified neutral theory of biodiversity and biogeography. Princeton University Press, Princeton

Huppert H (1975) Some remarks on the initiation of inertial Taylor columns. J Fluid Mech 67:397-412

Huston MA (1996) Biological diversity: the coexistence of species on changing landscapes. Cambridge University Press, New York

> Järvinen O (1982) Species-to-genus ratios in biogeography: a historical note. J Biogeogr 9:363-370

Koslow JA, Gowlett-Holmes K, Lowry JK, O'Hara T, Poore GC, Williams A (2001) Seamount benthic macrofauna off southern Tasmania: community structure and impacts of trawling. Mar Ecol Prog Ser 213:111-125

Legendre P, Legendre L (1998) Numerical ecology. Elsevier, Amsterdam

Leibold MA, Holyoak M, Mouquet N, Amarasekare P and others (2004) The metacommunity concept: a framework for multi-scale community ecology. Ecol Lett 7:601-613

Lessios HA, Kessing BD, Robertson DR (1998) Massive gene flow across the world's most potent marine biogeographic barrier. Proc R Soc Lond B 265:583-588

> Levin LA, Etter RJ, Rex MA, Gooday AJ and others (2001) Environmental influences on regional deep-sea species diversity. Annu Rev Ecol Syst 32:51-93

Ludäscher B, Altintas I, Berkley C, Higgins D and others (2006) Scientific workflow management and the Kepler system. Concurrency and Computation. Practice \& Experience 18:1039-1065

MacArthur RH, Wilson EO (1967) The theory of island biogeography. Princeton University Press, Princeton

Magurran AE (2003) Measuring biological diversity. Blackwell, Oxford

MarBEF (Marine Biodiversity and Ecosystem Functioning) (2004) European marine biodiversity datasets. Available at: www.marbef.org/data/imis.php? module=dataset

> McClain CR (2007) Seamounts: identity crisis or split personality? J Biogeogr 34:2001-2008

> McDougall I, Duncan RA (1988) Age progressive volcanism in the Tasman Seamount. Earth Planet Sci Lett 89:207-220 
Mohn C, Beckmann A (2002) The upper ocean circulation at Great Meteor Seamount Part I: structure of density and flow fields. Ocean Dyn 52:179-193

Mouquet N, Munguia P, Kneitel JM, Miller TE (2003) Community assembly time and the relationship between local and regional species richness. Oikos 103:618-626

Mullineaux LS, Mills SW (1997) A test of the larval retention hypothesis in seamount-generated flows. Deep-Sea Res I 44:745-770

Parin NV, Mironov AN, Nesis KN (1997) Biology of the Nazca and Sala y Gomez submarine ridges, an outpost of the Indo-West Pacific fauna in the eastern Pacific Ocean: composition and distribution of the fauna, its communities and history. Adv Mar Biol 32:145-242

Parker T, Tunnicliffe V (1994) Dispersal strategies of the biota on an oceanic seamount: implications for ecology and biogeography. Biol Bull 187:336-345

Poulin R, Mouillot D (2003) Host introductions and the geography of parasite taxonomic diversity. J Biogeogr 30: 837-845

R Development Core Team (2007) R: a language and environment for statistical computing. R Foundation for Statistical Computing, Vienna. Available at: www.R-project.org

Rao VP (1986) Phosphorites from the Error Seamount, northern Arabian Sea. Mar Geol 71:177-186

Rex MA, McClain CR, Johnson NA, Etter RJ, Allen JA, Bouchet P, Waren A (2005) A source-sink hypothesis for abyssal biodiversity. Am Nat 165:163-178

Rex MA, Etter RJ, Morris JS, Crouse J and others (2006) Global bathymetric patterns of standing stock and body size in the deep-sea benthos. Mar Ecol Prog Ser 317:1-8

Richardson PL (1980) Anticyclonic eddies generated near the Corner Rise seamounts. J Mar Res 38:673-686

Richer de Forges B, Koslow JA, Poore GCB (2000) Diversity and endemism of the benthic seamount macrofauna in the Southwest Pacific. Nature 405:944-947

Ricklefs RE (1987) Community diversity: relative roles of local and regional processes. Science 235:167-171

Ricklefs RE (2004) A comprehensive framework for global patterns in biodiversity. Ecol Lett 7:1-15

Roden GI (1987) Effects of seamounts and seamount chains on ocean circulation and thermohaline structure. In: Keating BH, Fryer P, Batiza R, Boehlert GW (eds) Seamounts, islands, and atolls. Geophysical Monograph 43, American Geophysical Union, Washington, DC, p 335-354

Rogers AD, Morley S, Fitzcharles E, Jarvis K, Belchier M (2006) Genetic structure of Patagonian toothfish (Dissostichus eleginoides) populations on the Patagonian Shelf and Atlantic and western Indian Ocean sectors of the Southern Ocean. Mar Biol 149:915-924

Rogers AD, Baco A, Griffiths HJ, Hall-Spencer JM (2007) Corals on seamounts. In: Pitcher TJ, Morato T, Hart PJB, Clark MR, Haggan N, Santos RS (eds) Seamounts: ecology, conservation and management. Fish and Aquatic Resources Series 12, Blackwell, Oxford, p 141-169

Rowden AA, Warwick RM, Gordon DP (2004) Bryozoan biodiversity in the New Zealand region and implications for marine conservation. Biodivers Conserv 13:2695-2721

Samadi S, Bottan L, Macpherson E, De Forges BR, Boisselier MC (2006) Seamount endemism questioned by the geographic distribution and population genetic structure of marine invertebrates. Mar Biol 149:1463-1475

Simberloff DS (1970) Taxonomic diversity of island biotas. Evolution 24:23-47

Smith DK (1988) Shape analysis of Pacific seamounts. Earth Planet Sci Lett 90:457-466

Somerfield PJ, Olsgard F, Carr MR (1997) A further examina- tion of two new taxonomic distinctness measures. Mar Ecol Prog Ser 154:303-306

Stocks K (2005). SeamountsOnline: an online information system for seamount biology, Version 3. Available at: http://seamounts.sdsc.edu/

Stocks KI, Hart PJB (2007) Biogeography and biodiversity of seamounts. In: Pitcher TJ, Morato T, Hart PJB, Clark MR, Haggan N, Santos RS (eds) Seamounts: ecology, conservation and management. Fish and Aquatic Resources Series 12, Blackwell, Oxford, p 255-281

Stocks KI, Condit C, Qian X, Brewin PE, Gupta A (in press) Bringing together an ocean of information: an extensible data integration framework for biological oceanography. Deep-Sea Res II

Swearer SE, Shima JS, Hellberg ME, Thorrold SR and others (2002) Evidence of self-recruitment in demersal marine populations. Bull Mar Sci 70:251-271

Tucholke BE, Smoot NC (1990) Evidence for age and evolution of Corner Seamounts and Great Meteor Seamount chain from multibeam bathymetry. J Geophys Res 95: 17555-17569

UNESCO (1983) Algorithms for computation of fundamental properties of seawater. UNESCO Tech Pap Mar Sci 44: $15-24$

US Department of Commerce (2006) Two-minute gridded global relief data (ETOPO2v2). Available at: www. ngdc. noaa.gov/mgg/fliers/06mgg01.html

Vermeij GJ (2004) Island life: a view from the sea. In: Lomolino MV, Heaney LR (eds) Frontiers in biogeography: new directions in the geography of nature. Sinauer Associates, Sunderland, MA, p 239-254

- Wares JP, Gaines SD, Cunningham CW (2001) A comparative study of asymmetric migration events across a marine biogeographic boundary. Evolution 55:295-306

Warwick RM, Clarke KR (2001) Practical measures of marine biodiversity based on relatedness of species. Oceanogr Mar Biol Annu Rev 39:207-231

> Webb CO, Ackerly DD, Mcpeek MA, Donohue MJ (2002) Phylogenies and community ecology. Annu Rev Ecol Syst 33:475-505

Wessel P (2001) Global distribution of seamounts inferred from gridded Geosat/ERS-1 altimetry. J Geophys Res 106:19431-19441

Wessel P (2007) Seamount characteristics. In: Pitcher TJ, Morato T, Hart PJB, Clark MR, Haggan N, Santos RS (eds) Seamounts: ecology, conservation and management. Fish and Aquatic Resources Series 12, Blackwell, Oxford, p 3-25

- Wessel P, Lyons S (1997) Distribution of large Pacific seamounts from Geosat/ERS-1: implications for the history of intraplate volcanism. J Geophys Res 102:22459-22475

White M, Mohn C (2004) Seamounts: a review of physical processes and their influence on the seamount ecosystem. OASIS report, NUIG and OASIS, Hamburg

White M, Bashmachnikov I, Arístegui J, Martins A (2007) Physical processes and seamount productivity. In: Pitcher TJ, Morato T, Hart PJB, Clark MR, Haggan N, Santos RS (eds) Seamounts: ecology, conservation and management. Fish and Aquatic Resources Series 12, Blackwell, Oxford, p 65-84

Whittaker RJ (1998) Island biogeography: ecology, evolution, and conservation. Oxford University Press, Oxford

Wiens JJ, Donoghue MJ (2004) Historical biogeography, ecology and species richness. Trends Ecol Evol 19:639-644

Wilson RR, Kaufmann RS (1987) Seamount biota and biogeography. In: Keating BH, Fryer P, Batiza R, Bochlert G (eds) Seamounts, islands, and atolls. Am Geophys Union Geophys Mon 43:355-378

Submitted: February 25, 2008; Accepted: February 25, 2009

Proofs received from author(s): April 28, 2009 